\title{
Cage 14: The Orangutan
}

\section{Christina Yin}

Swinburne University of Technology, Malaysia

\begin{abstract}
Cage 14: The Orangutan tells the true story of Bullet, the iconic and most well-known orangutan in Sarawak, Malaysian Borneo. The researcher-writer traces Bullet's story from his infancy when he survives gunshot wounds and is named for the bullet removed from his head by a medical doctor, until his incarceration in Cage 14 at Semenggoh Wildlife Centre. It is the story of an orangutan who, in his youth, mimicked his keepers and forest guards, and who throughout his life, preferred the ground to the trees. This orangutan, who chose to stand upright on two legs with his arms folded across his chest, stands posed in such a way today, stuffed and immortalised in a glass display case at Matang Wildlife Centre where rescued and confiscated wildlife are brought to be treated and rehabilitated. Pieced together from interviews with individuals who interacted with Bullet, this creative non-fiction ${ }^{1}$ work is a gothic tale of an orangutan's life at the mercy of his primate cousins, humans.
\end{abstract}

Keywords: Orangutan, Gothic, Animal welfare, Creative non-fiction, Sarawak, Borneo, Tropics

1 Creative non-fiction is a hybrid genre involving fact and imagination. As Miller and Paola (2012) state, "Imagination coupled with facts form this hybrid genre that is both exciting and so challenging to write". It is "an alive and evolving form of writing" (Prentiss \& Willkins 2014). It includes immersion in societies and life experience such as what anthropologists do, and narrative journalism such as that written by George Orwell and Tracy Kidder (Perl \& Schwartz 2014). 


\section{The Photograph, 1992}

B ullet folds his arms across his chest. He is standing upright on his legs like a human, staring directly at the camera between the bars of the belian ${ }^{2}$ cage. His hair is shaggy, his arms orange, face brown with large flanges, body and legs reddish-brown. Bullet is looking right at the person taking the photograph; in an eerie way, it seems as if he is contemplating the humans and their actions rather than the other way around. ${ }^{3}$ It's 1992 and the young Executive Forester who takes the unsettling photograph has brought students to Semenggoh Wildlife Centre for conservation education activities. He is mesmerised by the orangutan's eyes. They are so knowing. Behind the shaggy hair, Bullet is thinking.

Bullet moves in a circle in the cage, his arms still crossed, legs pacing. He walks like a human, upright on two legs. Unlike other orangutans, he rarely drops down onto his long arms. Those arms are held against his chest as if he were protecting something precious, or as if he were deep in thought. The young Executive Forester, Melvin Gumal, wonders what Bullet is thinking as he and the students watch the orangutan pace in his cage. There is something so human about the shaggy red ape.

The vet, Dr Jane Bennett, says Bullet is angry; his pacing and folded arms are indicators of frustration. Christopher Kri anak Ubang, who cared for him when he was a young orangutan at what was then the Semenggoh Orangutan Rehabilitation Centre, says Bullet just feels comfortable standing upright with his arms crossed over his chest. Abang Mutalib bin Abang Tajudin, a Forest Guard who worked at Semenggoh, says the posture shows he is happy. He is, after all, Abang Mutalib reasons, the most famous orangutan at the wildlife centre.

Visitors to Semenggoh are fascinated by Bullet. They come and stand outside his cage just looking at him; exclaiming, astonished. He is large, dwarfing the other confined and semi-wild orangutans. His immense size and colourful hair attract children and

\footnotetext{
${ }^{2}$ Belian is what Sarawakians and Sabahans call Eusideroxylon zwageri, a hardwood tree belonging to the family Lauraceae found in Borneo, Sumatra and the Philippines. Valued for its properties of being extremely hard and resistant, it is also known as "Borneo ironwood" and is used in the construction industry.

${ }^{3}$ In her work 'Apes and elephants: in search of sensation in the tropical imaginary', Barbara Creed (2013, p.159) describes how in the $19^{\text {th }}$ century, people were drawn to the first modern zoos as they "offered a place of retreat, an opportunity to learn about nature, and the possibility of experiencing the thrill of an encounter with wild and exotic animals which might awaken 'dreams and ancient desires'." Visitors to Semenggoh come expressly to view the semi-wild orangutans in the flesh; fascinated, perhaps by their humanoid appearance. Captured in this photograph, Bullet appears to be returning the favour, observing the humans in a strangely human-like stance, arms folded across his chest, standing upright on two legs.
} 
adults alike. Some foreign visitors are unhappy that he is confined in what seems to be a small cage. His rapid pacing back and forth across the tiny enclosure troubles them. They write letters of complaint and eventually, the authorities order the building of a larger enclosure for him.

In 1990, Abang Mutalib is sent to study conservation and wildlife rehabilitation at Jersey Zoo run by the Durrell Wildlife Conservation Trust. ${ }^{4}$ When he returns a year later, he supervises the construction of the larger enclosure for Bullet. It has become impossible for Bullet to be allowed to wander freely at the wildlife centre as other orangutans are allowed to do. Instead of disappearing into the nature reserve and foraging for fruits in the trees, Bullet prefers to roam the grounds of the wildlife centre. $\mathrm{He}$ investigates the barracks, the offices, the tree nursery and human activities.

As a young orangutan, he would slide up to visitors. He loved to stroke their legs. Bibiana Pek who regularly visited Semenggoh in the early 1980s with her children and husband Abang Haji Kassim bin Abang Morshidi, then the National Parks and Wildlife Officer, remembers how he would come right up to her and stroke her leg. He loved to imitate humans, pushing the wheelbarrow, picking up a hammer. But as he grew older, he became bigger and stronger. He chased and attacked too many people, including Abang Mutalib, who worked at the wildlife centre when Bullet was young and still allowed to roam on the grounds at will. He even bit Johnwen anak Sian, who cared for him every day for years, and Dr Jane Bennett, the vet who treated him with great empathy and humanity.

\section{The Orangutan Ancestor}

In the longhouses near Batang Ai National Park in Seri Aman Division, the Iban villagers believe that their ancestors were once orangutans. There is a parang ${ }^{5}$ treasured by the people in the Nanga Delok longhouse because it was given to an old man by a stranger he had met in the forest, three or four generations ago. As they exchanged parangs, this stranger told the old man, "We are brothers now. I am a human, but I was an orangutan originally. Never kill an orangutan." So, the old man went back to the longhouse and told his family and his relatives never to harm orangutans because they were all brothers and sisters. Years later, when the old man lay dying, he told his people that when he died, they should not bury him, but leave him at a certain place on a hill named Bukit Seligi. This they did, and after they had

\footnotetext{
${ }^{4} \mathrm{Dr}$ Jane Bennett helped write the proposal that enabled Abang Mutalib to study at Jersey Zoo where Gerald Durrell, the British naturalist, zookeeper and conservationist, had established a conservation academy to train people from all around the world, equipping them with knowledge and skills to help conserve species in their homelands.

${ }^{5} \mathrm{~A}$ long knife or machete used in the forest as a tool, for example: to cut a pathway or wood to build a fire for cooking, or for protection or hunting.
} 
laid him down in that place, his body disappeared. At that moment, they heard an orangutan call from afar. The people believe that the old man had died as a human, but then lived again as an orangutan. To this day, the people of Nanga Delok longhouse will not hunt nor harm orangutans.

Barbara Creed writes of the merging of human and animal in her 2011 paper Tropical Malady. Her analysis finds writers and film makers exploring the line between human and animal and the uncanny possibilities that Darwin's theory of evolution seemed to suggest. In their study of the cultural history of the orangutan, the so-called wild man of Borneo, Cribb, Gilbert and Tiffin (2014) describe how early Western exhibitions used the rare live specimens of orangutans to "challenge the human-ape boundary". Yet, in the story of the orangutan ancestor at Nanga Delok, the forest guard Mohammad Irwin Abdullah whose Iban name is Enggoh Glak, was very matter of fact and displayed neither fear nor awe when he told me the ancestral tale.

When I asked him if he believed the story, Enggoh said simply that although he had not seen the parang that had been given to the old man by the human-orangutan, and which was supposed to still be at the Nanga Delok longhouse, the indigenous people there respected the orangutans in the forest around them. They never hunted or killed them.

Westerners of the seventeenth and eighteenth centuries, who longed to see the exotic and who were thrilled by the possibilities of a hybrid human-orangutan, embraced stories of our cousins. In fact, the humanlike behaviour of walking on two legs and the uncanny resemblance to our species led some to believe that an orangutan was "something more than an animal, even if it might be something less than a human" (Cribb, Gilbert \& Tiffin 2014). Creed's paper exploring the human fascination with the animal-human connection, shape-shifting and hybrid humans, shows us that the gothic story continues in our imagination, while wildlife centres are sites for live orangutan reality shows so similar to the reality TV shows that supposedly reveal how people actually live and interact with one another. To thousands of visitors, watching the orangutans at a wildlife centre is a happy, exciting experience; to others, it reveals the reality of sad and diminished lives. Today, some confiscated infant orangutans raised in human households have grown to be semi-wild in Semenggoh Wildlife Centre while others that cannot adapt to life in the forest reserve must remain confined where they cannot trouble humans. Thus, if the Iban myth at Nanga Delok were a true story, some of our brothers and sisters survive in a semi-wild state while others are caged for life; their physical strength, periodic aggression, and affinity to humans and life in our built areas, rendering them too dangerous to be allowed to roam free. 


\section{Semenggoh Wildlife Centre, 2018}

I'm a city dweller and not a frequent visitor to the forest. Semenggoh Nature Reserve is about 20 kilometres from the city centre of Kuching, and is proudly advertised as "the largest Orangutan Rehabilitation Centre in Sarawak". Leaving our car outside the main entrance and guard house, we walk past the Botanical Research Centre, and then along a narrow road that follows a slope up a hill. It's still early in the morning and not yet too humid. We've come in the hope to see the semi-wild orangutans visiting the feeding platforms for a meal. The fruit will be laid on the platforms at 9:00 am and as it's not the fruiting season, chances are good that some of the semi-wild orangutans will appear.

We pass the arboretum on our left and the tree nursery on our right. Melvin points out orangutan nests - some old, some fresh - high in the canopy of tropical trees rising up around us. It's been twenty-six years since he came here as a young Executive Forester with students. Now, Semenggoh Nature Reserve is filled to capacity with semi-wild orangutans that were confiscated from illegal hunters or villagers' homes. The nests are an indication that the animals have learned or re-learned the daily task of a wild orangutan. They are breeding, too. This is a contentious issue among conservationists; some believe breeding captive wildlife, even if they're semi-wild, is a mistake. At 653 hectares, the nature reserve is too small for the growing population of 22 animals, but it is too dangerous to release the orangutans into other sites where existing colonies may attack newcomers. It is also unsafe to release the orangutans into areas that are not known orangutan habitats as they might be unsuitable and unable to sustain the primates. The two known attempts of releasing orangutans into the wild in Sarawak resulted in their starvation and death; Barbara Harrisson's release of orangutans in the 1970s at Bako National Park, and the doomed release of three young animals in the 1980 s at Sebuyau.

Semenggoh Wildlife Centre is not ideal, but it's a far cry from the artificial enclosures and cement "trees" found in some zoos. Here at least, the semi-wild orangutans live in the rainforest, building nests for their rest, foraging among the fruit trees and only visiting the feeding platforms when the trees are not fruiting. I wonder, though, what will happen as the population continues to grow. Will the animals forage further afield into the orchards in the nearby village? What will the villagers do?

About ten minutes later, we reach the main visitor's area. A crowd of local and foreign visitors gathers at the viewing station overlooking the main feeding platform. Edwin, one of the alpha males, is slowly picking up a banana, his back turned towards us. Two young adults make their way down the trees, one stretching its hind limbs in a 
perfect split to grasp branches as it lowers itself slowly, shifting to hold itself steady with one hand on a rope, the other reaching down cautiously for some fruit. They are surely aware of the crowd gawking at them; the cameras clicking, and the excited chatter of humans. What do they make of us?

When feeding time is over and the crowds have left, Melvin's former colleague, Park Ranger Dominic Eric Helan, lifts the barrier and we make our way along the wooden walkway, past the smaller cages, 1 to 13 . Once they housed gibbons and orangutans, even hornbills. ${ }^{6}$ They are all empty and abandoned now. Since 2000 , rescued and confiscated wildlife have been taken to Matang Wildlife Centre, allowing Semenggoh to remain the home of the semi-wild population of orangutans and to serve as a major tourist attraction. Visitors are encouraged to come to Semenggoh and the numbers are remarkable. Dominic tells us there were 20,000 visitors in May 2018 alone.

The wooden walkway is slick from yesterday's rain and the morning dew. Some boards are bowed down and broken through. Scatterings of leaves and moss cover the boards. All around us, between and behind the cages, trees, palms and ferns rise in a tangle of branches and leaves, sheltering us from the heat of the day. Cage 14 is the last enclosure. Beyond it, the forest rises like a thick curtain of brown and green. The air is cool here, and I hear cicadas and the gentle rustle of leaves; sounds I can't hear when surrounded by the humming of the air conditioner at my workplace, or the rush of the cars, lorries and motorbikes on the roads.

I step into Cage 14. The iron bars are covered with creepers and ferns. Branches from the nearby trees shade the cage where now only plants and a sandy floor are enclosed. Further inwards, a smaller cage is connected to the main enclosure. This cage had been built first as a result of the complaints from foreign visitors who had been appalled by the tiny space that the belian cage had afforded Bullet. When Abang Mutalib returned from his training at Jersey Zoo's conservation academy, he was aware that much more was needed. Under his supervision, a larger cage was built. The two enclosures were connected so that Bullet could be confined to the smaller cage when the larger enclosure was being cleaned and vice versa, keeping workers safe. Abang Mutalib's newly acquired knowledge and training in wildlife management, as well as Bullet's increasingly aggressive behaviours, brought about these changes. It was here that Bullet lived out the remainder of his life; in the two enclosures that formed Cage 14 at the end of a narrow wooden walkway, on the edge of the nature reserve where his semi-wild relatives roamed freely. Standing in Cage 14 now, the

\footnotetext{
${ }^{6}$ Sarawak is known as Bumi Kenyalang, the Land of the Hornbills; eight species of this majestic bird can be found in the state, with the iconic Rhinoceros Hornbill being both the state and national bird. Revered in local folklore and legend, and coveted for its casque and feathers, the bird is now endangered and deemed Totally Protected under the Wild Life Protection Ordinance (1998).
} 
dense surrounding forest presses down on me. What must Bullet have thought, to be able to see the forest but never again to feel the earth beneath his feet, never again to touch the bark of the trees, never again to forage among the branches and leaves?

\section{Bullet - free and confined, from childhood to adulthood, 1973 - 1992}

The orangutan is an arboreal ape. In the wild, it spends most of its time in the trees, but Bullet spent most of his life on the ground. Even when allowed to roam at Semenggoh as a young orangutan, Bullet preferred to remain terrestrial, imitating the humans around him. His keeper, Christopher Kri anak Ubang, says Bullet never seemed to like being in the trees. He loved to be with humans. When he was young, he followed Christopher Kri around Semenggoh, sometimes grasping his leg and hugging it as Christopher Kri went about his duties; other times mimicking his actions, picking up tools and trying to use them. He would go to sleep on the floor next to Christopher Kri's bed; his favourite sleeping position being flat on his belly. He would put on a sarong and pull it up over his head, then lie on the floor on his stomach.

It is hard to imagine that the young orangutan living freely at Semenggoh like a beloved child to his keepers Christopher Kri, Thulu Ayu and Bujang Malik, and to the visitors like Bibiana Pek and her children, would eventually live most of his life in a cage. All those who looked after him say he became more aggressive. The trigger, apparently, was when a mischievous Forest Guard cut Bullet's hair and showed him his own reflection in a mirror. ${ }^{7}$

Did Bullet believe he was a human being? Was the sight of his face in the mirror a horrible shock? The young orangutan had been orphaned as an infant, shot in the head when his mother was killed. With no wildlife vets in Kuching at that time, Bullet had been operated on by Dr Daniel Kok, a medical practitioner in town. Named for the bullet that Dr Kok removed, the young orangutan was raised by Dr Kok's American wife Elizabeth; he lived with their family for about three years, until Semenggoh was established as an orangutan rehabilitation centre. Growing too big and strong, Bullet was translocated from the Kok family's residence in Batu Lintang to Semenggoh.

Perhaps this human family life that Bullet had enjoyed was all that he knew about life and family. Did Bullet only remember his human mother and the family ways he

\footnotetext{
${ }^{7}$ According to Cribb, Gilbert and Tiffin (2014, pp. 235-236), Darwin himself gave a mirror to two captive orangutans in a zoo. It appeared that their reaction revealed a lack of self-awareness, though they could express emotion. In Bullet's case, some forest guards believe that seeing himself in a mirror made Bullet realise that he was different from the humans he had bonded with, leading to anger and increasingly aggressive tendencies.
} 
learned from living with a human family for three years? Did seeing his own reflection prove to be a gothic nightmare from which he could never wake?

\section{In Cage 14, 2018, Reflections}

I look out through the bars of Cage 14 . The forest surrounds the cage with only a small gap cleared so that the keepers and visitors can approach Cage 14 from the mossy wooden pathway. This small open space in the forest and the pathway are what Bullet would have seen. As a young orangutan, he had loved being with people. In the cage, he could no longer touch humans nor play among them as he had done. Female orangutans were brought into the cage in the hope that he might father offspring, but he was not interested in them. Eventually, the females were taken out of the cage and Bullet was left alone. His only interactions were through the bars of the cage. Visitors would trek along the walkway to seek him out in Cage 14, to gawk and gaze at him.

Trying to establish a friendly relationship with him, the wildlife vet Dr Jane Bennett would give Bullet's hand a pat before she left every evening. Then one day in 1989, Melvin heard a huge commotion when he was carrying out conservation education activities with a group of students at Semenggoh. Bullet had bitten Dr Bennett's hand and would not let her go. It seemed that he had turned her friendly gesture into an opportunity to express his pent up rage. Finally, the park staff managed to get Bullet to release Dr Bennett, but by then, his powerful bite had severed a ligament in her hand. What had caused Bullet to turn on Dr Bennett? Why had he bitten a human who treated him with kindness and compassion?

Humans created the damaged Bullet. Greed or maybe desperation had led to the killing of Bullet's mother. Saved by Dr Kok, Bullet lived his childhood years with a human family. That life was disrupted when he was taken to Semenggoh where he was initially allowed to roam free during the day. His companions were forest guards and general workers. Could it have been mistreatment or was it the realisation that he was different from humans that had led to Bullet becoming aggressive?

Cage 14 and all those other cages at Semenggoh are abandoned now, but the tale of injured, rescued and confiscated wildlife continues. Bullet's stuffed body stands upright in a glass case at Matang Wildlife Centre; the taxidermist had chosen to fix him in his favourite pose for posterity. It is as if he is forced to witness the repetition of the horror stories of rescued and confiscated wildlife that are brought to join the menagerie of damaged caged animals at Matang. Will they ever be rehabilitated and released into the wild? The aim is to do so, but many may not be able to; they were either captured too young to learn how to fend for themselves in the wild, or are too damaged from years of captivity or ill treatment. A few might have a chance to be rehabilitated, except 
that there are no forests for them to be released into. Existing populations of their species in the protected forests or national parks might attack them, while the food and prey in other forests may be scarce or unsuitable for their consumption. It is possible that most will spend the rest of their days in cages visited only by humans who seek Darwin's "backbone shiver" of which Barbara Creed (2013, p. 168) says the human animal yearns: "to feel the thrill of fully being alive in the modern world." This thrill is gained at the cost of the mythic human-orangutan confined in a cage or in a small patch of nature reserve never truly living in a natural state. This is the gothic horror story that haunts human civilisations, demonstrating that we are not really that civilised after all. The photograph of Bullet and the abandoned Cage 14 remind me of this. 
eTropic 18.2 (2019) 'Tropical Gothic: Literary and Creative Works' Special Issue | 67

\section{References}

Creed, B. (2013). 'Apes and elephants: in search of sensation in the tropical imaginary' eTropic, 12 (2), 156-170. DOI: https://doi.org/10.25120/etropic.12.2.2013.3339

Creed, B. (2011). 'Tropical malady' eTropic, 10, 131-140. DOI:

https://doi.org/10.25120/etropic. 10.0.2011.3414

Cribb, R., Gilbert, H. \& Tiffin, H., (2014). Wild man from Borneo: a cultural history of the orangutan. Honolulu, HI: University of Hawaii Press.

The Commissioner of Law Provision 2008, 'Wild Life Protection Ordinance 1998' in Laws of Sarawak.

Miller, B. \& Paola, S. (2012). Tell it Slant: Creating, Refining and Publishing Creative Nonfiction, $2^{\text {nd }}$ ed. NY: McGraw Hill.

Naimah, C.L., (2014). Eusideroxylon zwageri: the official tree of Sarawak, The Forest Research Institute of Malaysia, https://www.frim.gov.my/colour-of-frim/eusideroxylonzwageri-the-official-tree-of-sarawak/wppaspec/oc1/cv0/ab88/pt357

Perl, S. \& Schwartz, M. (2014). Writing True: The Art and Craft of Creative Nonfiction, $2^{\text {nd }}$ ed. Boston: Wadsworth.

Prentiss, S. \& Wilkins, J. (Eds.) (2014). The Far Edges of the Fourth Genre: An Anthology of Explorations in Creative Nonfiction. East Lansing, MI: Michigan State University Press. 